\title{
Translating Gjergj Fishta's epic masterpiece, Lahuta e Malcis, into English as The Highland Lute
}

\author{
Janice Mathie-Heck, \\ Translator, Poet, and Literary Critic
}

Both Robert Elsie and I are delighted that our translation of Gjergj Fishta's Lahuta e Malcis (the Albanian national epic) has emerged into the light of day, and that it will receive exposure to a worldwide readership. We worked hard on it, line by line, and are pleased with how The Highland Lute sounds in English. The epic poem contains 15,613 lines. It mirrors Albania's difficult struggle for freedom and independence which was finally achieved in 1912. It was important for us to achieve an atmosphere similar to that of other important European epics such as Beowulf (England), The Kalevala (Finland), and the grand medieval poems of the eleventh and twelfth centuries such as The Song of Roland (France), Nibelungenlied (Germany), and Poem of the Cid (Spain). Rhythmically, The Highland Lute is very much like the American writer Henry Wadsworth Longfellow's epic poem, Hiawatha, parts of which I loved to recite as a young girl.

Of course, Fishta wrote in the old Gheg language of northern Albania which was his natural and native tongue. He was strongly influenced by both the traditional oral epics of his own culture and by the Greek epics such as the Iliad, the Odyssey, and the Latin Aeneid. He also admired the Montenegrin national epic, The Mountain Wreath, by Njegosh (1847). I believe that he was consciously preserving the historical and linguistic dimension of the era in which events described in The Highland Lute took place -- that is, in the latter part of the 19th century and the first part of the 20th -- from 1862 to 1913 . He also felt that Gheg was perfect for a literary language. As with English dialects, the Gheg dialect has evolved over the years, and Fishta's original words are difficult to understand for many Albanian readers today. To illustrate, when one looks at the original text of the English epic, Beowulf, it is almost impossible to decipher, and was revised recently and very successfully by Seamus Heaney of Ireland, winner of the Nobel Prize for Literature in 1995.

Our task with translating The Highland Lute into English has been to make the language relevant and understandable for the modern reader while still retaining its colloquial, archaic, majestic, and heroic feel which gives a strong 
sense of the past. Quite a challenge! We translated many expressions unique to Gheg, and did our best to describe symbols of Albanian mythology and legend such as oras (female spirits), zanas (protective mountain spirits), draguas (semi-human figures with supernatural powers), shtrigas (witches), lugats (vampires), and kulshedras (seven-headed dragon-like creatures). We kept the octosyllabic rhythm consistent throughout, and we captured the qualities common to all epics: alliteration, assonance, repetition, hyperbole, metaphor, archaic figures of speech, concrete descriptions, colour, drama, passion, a range of emotions, intensity, sensuality, lots of action, rhyme where possible, and an exalted, dignified tone.

Of course, translation is never a simple matter. One can't merely switch the words of the original language into neatly corresponding words and phrases of the new one. We sometimes had to rearrange the word order and needed to use some old-style phrases and poetic expressions. In this way, we were more faithful to the original Albanian (which uses exact metre, assonance, and rhyme) than a more literal translator would have been. We wanted to preserve the nuances and "meanings between the lines", and retain the flavour of the original. So we attempted to keep the essence, the fragrance, the spice, and the colour with all of the devices we had at our disposal.

The following stanzas are taken from Canto 24 - The Zana of Mount Vizitor. They illustrate the almost-finished draft with the suggested final revisions to be made.

Thus when on that promontory

Sitting up, the Good One noticed

How in Nokshiq war was raging,

She surveyed Curr Ula's courtyard,

And she saw what she had dreaded,

220 Had her eyesight but been weaker!

Saw her Tringa dead and lifeless, (take out "perished")

Lying stretched across the courtyard, Severed (again, "Sawed-off" sounds like a shotgun...) head beside the doorway

In a pool of blood, and shuddered. (Take out "quivered")

225 Down her spine did run the shivers.

Yes, the Good One could not fathom,

Not accept that something evil

Could occur and fell (take out "strike") her Tringa. 
To her sight (take out "eyes") she gave no credence,

230 And her hand, as fair as sunshine, Did she place upon her forehead, (take out "above her eyebrows")

Stood up straight upon the cliff side,

Up and down her head was bobbing,

Raised her eyebrows, bolts of lightning,

235 Lowered then her lids (take out "eyes") in sorrow,

Like a mother when she learns

The foe has slain (take out "killed") her son in battle,

In the Highlands or the lowlands,

Or some other peril's struck him,

240 When the others bring the message,

Not to break her heart entirely,

With a vague word or a "maybe." (Take out "vaguely worded")

To her feet will rise the mother

At the news and set off running,

245 But her aged legs (take out "legs with age") won't bear her.

Thus in anguish she starts hoping (take out "thinking")

It won't be her son who's perished,

It will be another fighter

Who perchance bears the same surname. (Take out "will have the same")

250 She refuses to imagine

That her son could be in danger.

When she nears the sad location,

Does she see her son has perished,

With an "ah" she gives a whimper, (take out "yammer")

255 Beats her head, that withered widow,

Pain within her heart a-welling. (Take out "rising")

So it was with the fair Zana,

When she saw that Tringa'd perished.

From the lofty promontory

260 Did the Good One like an arrow

Shoot into the air, a-soaring,

On her golden wings descended,

As a pigeon plummets to a

Threshing field for grain, she sped fast (take out "speeded")

265 To the courtyard of Curr Ula,

Curr lay dead beside the chimney,

In the courtyard sprawled (take out "lay") his sister. 
As a mother, when at night

Her children at the hearth are dozing,

270 Hugs them in her arms and bears them, (add comma)

Cuddled, (add comma) off to bed for sleeping,

So the zana fondled Tringa,

In her warm embrace, (take out "Took her in her arms") caressing,

Petted, coaxed her head with care and (take out "so gently,")

275 In her snow-white arms she held her,

Being rocked to sleep, you'd think her.

To her breast the Earthly Beauty

Clasped the corpse, a-flying (take out "body" and "soaring") upwards

To the heavens, through the shooting,

280 Through the cannonballs and bullets,

Flew to Vizitor, that mountain,

Where she gently laid the body.

On that mountain pass, a pasture (take out "meadow")

Stretched beside a pine-tree forest,

285 Stone-throw wide did span (take out "stretch") that (take out "the") meadow,

Full of verdure and young flowers.

In the middle of the meadow

There arose a lofty boulder,

At its foot an icy spring flowed,

290 Cold spring water coursed (take out "flowed" )enough

To keep a millstone turning, milling.

There the oras and the zanas,

All assembled, took refreshment

In the moonlight bathing, and did

295 Join their hands (take out "in hand") to form a ring-dance.

There they danced and there made merry,

There waxed joyful (take out "made merry") with their singing,

We took great care to keep the text interlinear - one line of English for one line of Albanian. The German translation by Maximilian Lambertz, made in the late 1930s, sometimes employed up to seven lines of German to clarify and translate one line of Albanian. The Italian prose translation by Ignazio Parrino, made between 1968 and 1973, is interlinear, but lacks the true epic flavour.

This is a monumental epic poem dedicated to the Albanian people. It is a lyrical song of the soil, a song of blood and of battle, a song of idyllic green 
meadows and gracefully wise zanas, and we felt that it deserved to be told in the spirit of its originator -- with all of the emotional impact and full-bodied sense of adventure and love that Fishta possessed! It's truly a classic, but at the same time we feel that it comes alive for the reader in today's rich and colourful English language. I find it inspirational and thrilling -- especially when read aloud.

Gjergj Fishta revelled in the centuries-old, oral epic tradition of the northern Albanian highlanders. He lived in the Shkodra region, and had opportunities to hear "the singers of tales" performing for hours on their one-stringed lahutas. He befriended one in particular -- Marash Uci, who fought in the battle of the Rrzhanica Bridge, and the old man's stories enflamed Fishta's imagination to even greater heights. In my opinion, I think that Fishta would have become a warrior himself had he not chosen to be a priest! He had a keen sense of history, and he gloried in the descriptions of heroic battle scenes and of tribal warriors fighting to preserve their honour and to protect their homeland. He wanted his readership to be aware of the special laws and cultural customs of the highlands as embodied in the Code of Lekë Dukagjini, known as the "Kanun". In The Highland Lute, he vividly and eloquently described the social system, the patriarchal structure, the concept of the besa or keeping one's word, the tradition of hospitality towards guests, and the etiquette of blood feuding. The highlanders had kept their culture intact in spite of five centuries of Ottoman rule, and he saw them as models of flamboyance and bravery. They were still living, literally and figuratively, in a medieval fortress setting which he knew would eventually be changed through European influence. He was deeply committed to the freedom and independence of his country, and had lived through a time of many border skirmishes, plots, schemes, and military intrigues concerning the Turks and Slavs (Montenegrins) which forced retaliation by the Albanians -- in particular, his own proud and rugged mountain people. Fishta captured the living, breathing, vibrant verse rendered by real people who once loved, lusted, conquered, galloped, raided, mourned, sang, danced, feasted, plotted, wooed, hungered, suffered, won, coveted, shouted, slept, rejoiced, married, plundered, moaned, and fell in battle...!!!

Even though the first edition of The Highland Lute was published 100 years ago, it has universal significance. I am a teacher of English to new Canadians. Canada is a multicultural country which respects diversity of language, ethnicity, and religion. In this context, I would tell my students that the 
Albanian lands had been attacked and overrun by various ethnic groups over the centuries. The people had always tried to defend themselves against invaders with varying degrees of success. Somehow the northern Albanian tribes managed to keep their culture and sense of individuality even during the long reign of the Ottoman Empire. Like Fishta, they were optimistic. They had a strong, confident spirit! I think that Fishta was inspired by their sense of honour, justice, and fearlessness. He was a proud patriot, and saw Albania as an endangered nation which wanted to take its place beside the other autonomous nations of Europe.

Why did he write this epic poem? He wanted to stress a sense of collective identity. A knowledge of history, preserved through our literature, makes us able to share our ideas and beliefs while learning from and empathizing with the ideas and beliefs of others in the world community. We come to know many heroes and villains. Reading about what people did long ago in faraway lands enriches our perspective and gives us models and choices, both good and bad, of how we might live. This sense of common experience goes back to the beginnings of civilization and crosses all cultural barriers. Being aware of our similarities and our differences helps us to know ourselves and to be tolerant of others. We discover our heritage, our roots (where we came from), and how our own language and culture developed through the centuries. Hopefully, we can learn many lessons from the past and not repeat the mistakes of our ancestors. We can eventually learn to live together. In all these ways, Fishta's Lahuta e Malcis is timeless.

July 2008

Calgary, Alberta, Canada 